\title{
Perunan tyvimädän tunnistaminen infektiossa vapautuvien yhdisteiden perusteella
}

\author{
Carita Mikkola ${ }^{1}$, Elina Virtanen ${ }^{1}$, Eila Järvenpää2 ${ }^{2}$ Heikki Kallio ${ }^{2}$, Jyrki Kauppinen ${ }^{3}$, Juha Peura ${ }^{3}$, \\ Ismo Kauppinen ${ }^{4}$, Juha-Pekka Kotro ${ }^{4}$ ja Lea Hiltunen ${ }^{1}$ \\ ${ }^{1}$ MTT Pohjois-Pohjanmaan tutkimusasema \\ ${ }^{2}$ Turun yliopisto, Biokemian ja elintarvikekemian laitos \\ ${ }^{3}$ Turun yliopisto, Fysiikan laitos, optiikan ja spektroskopian laboratorio \\ ${ }^{4}$ Gasera Oy
}

\section{Tiivistelmä}

Erwinia-bakteerien aiheuttama tyvi- ja märkämätä on yksi pahimmista tautiongelmista perunantuotannossa. Tyvimätä on emomukulasta alkavaa ja siitä perunan varsiin leviävää mätänemistä, kun taas mukuloiden mätänemistä kutsutaan märkämädäksi. Mukuloita pilaava märkämätä aiheuttaa vuosittain suuria varastohävikkejä niin siemen- kuin ruokaperunatuotannossa. Taudin tekee erityisen ongelmalliseksi taudinaiheuttajien leviäminen oireettomana siemenmukulassa kasvikaudesta toiseen. Näkyvät tyvimädän oireet alkavat kehittyä vasta, kun mukulassa on riittävästi bakteerisoluja. Erwiniabakteerien infektioiden yhteydessä vapautuu haihtuvia yhdisteitä, jotka ovat näille bakteereille ominaisia. Jos nämä yhdisteet voidaan mitata ja määrittää luotettavasti, piilevän tyvimädän infektio voidaan havaita ennen oireiden ilmenemistä ja koko perunaerän/-varaston saastumista tai pilaantumista.

MTT Pohjois-Pohjanmaan tutkimusaseman, Turun yliopiston elintarvikekemian laboratorion, fysiikan laitoksen optiikan laboratorion ja Gasera Oy:n yhteistyönä toteuttaman tutkimuksen tavoitteena oli selvittää, voidaanko piilevä tyvimätä havaita Erwinia-bakteerien infektion yhteydessä vapautuvien haihtuvien yhdisteiden perusteella ennen näkyvien oireiden ilmenemistä. Perunalajikkeen Asterix mukuloita saastutettiin keinotekoisesti Erwinia carotovora alalaji atroseptica -bakteerilla ja säilytettiin huoneen- tai varastolämpötilassa. Haihtuvia yhdisteitä kerättiin eri ajankohtina ja analysoitiin SPMEGC-MS- ja FTIR -menetelmillä. Molemmilla menetelmillä voitiin osoittaa selvä ero terveestä ja Erwinia-bakteerilla saastutetusta perunasta vapautuvien haihtuvien yhdisteiden välillä. SPME-GC-MS menetelmällä ero havaittiin 15-18 ja FTIR-menetelmällä 12-18 tunnin kuluttua saastutuksesta, kun perunat säilytettiin huoneenlämpötilassa $\left(21-23^{\circ} \mathrm{C}\right)$. Näkyvät mätänemisen oireet alkoivat ilmetä 48 tunnin kuluttua saastutuksesta. Samanlainen selvä ero havaittiin saastutettujen ja saastuttamattomien perunoiden haihtuvissa yhdisteissä, kun perunoita säilytettiin varastolämpötilassa $\left(5^{\circ} \mathrm{C}\right)$. Inkubointiajan jatkuessa sekä haihtuvien yhdisteiden määrä että pitoisuudet kasvoivat. Saastuttamattomissa kontrollimukuloissa samoja haihtuvia yhdisteitä ei havaittu.

Sekä SPME-GC-MS- että FTIR -menetelmät soveltuivat perunoista vapautuvien haihtuvien yhdisteiden määritykseen laboratorio-oloissa, sillä molemmilla menetelmillä voitiin osoittaa selvä ero terveen ja Erwinia-bakteerilla saastutetun perunan välillä ennen näkyvien oireiden ilmenemistä. Menetelmien optimoinnilla ja validoinnilla voidaan saada tarkempia tuloksia mm. yhdisteiden absoluuttisista pitoisuuksista. Kumpikaan menetelmä ei sellaisenaan sovellu piilevän tyvimädän tunnistamiseen tuotanto-oloissa, mutta näillä menetelmillä voidaan kerätä aineistoa, joka mahdollistaa kenttäkelpoisen sovelluksen kehittämisen.

Avainsanat: peruna, piilevä tyvimätä, märkämätä, Erwinia-bakteeri, Erwinia carotovora alalaji atroseptica, haihtuvat yhdisteet, SPME-GC-MS, FTIR 


\section{Johdanto}

Yksi siemenperunatuotannon pahimmista tautiongelmista on Erwinia-bakteerien aiheuttama tyvi- ja märkämätä. Tyvi- ja märkämätää aiheuttavat Erwinia carotovora alalaji atroseptica (Eca), Erwinia carotovora alalaji carotovora (Ecc) ja Erwinia chrysanthemi (Ech). Tyvimätä on emomukulasta alkavaa ja siitä perunan varsiin leviävää mätänemistä, kun taas mukuloiden mätänemistä kutsutaan märkämädäksi. Kaikki mainitut bakteerit aiheuttavat märkämätää, sen sijaan tyvioireita tuottavat tavallisesti vain Eca ja Ech (Pérombelon \& Kelman, 1987). Mukuloita pilaava märkämätä aiheuttaa vuosittain huomattavia varastohävikkejä niin siemen- kuin ruokaperunatuotannossa. Mätänevät mukulat hajoavat valuvaksi bakteerimassaksi, joten yksikin mätänen erä voi varastossa saastuttaa alun perin terveet erät.

Taudin tekee erityisen ongelmalliseksi taudinaiheuttajien leviäminen piilevänä eli oireettomana siemenmukulassa kasvukaudesta toiseen. Kasvintuotannon tarkastuskeskus (KTTK) valvoo tyvimädän esiintymistä kasvustoissa sekä märkämädän esiintymistä varastoissa, sen sijaan piilevän tyvimädän määritys on vaikeaa ja sen esiintymiselle ei ole asetettu raja-arvoa. Kasvustossa näkyvien tyvimätäoireiden ja satomukuloiden piilotartunnan välistä yhteyttä ei tunneta eivätkä oireettomat mukulat ole siemenerän tautivapauden tae. Piilevän tyvimädän määritys perustuu yleensä oireiden havainnoimiseen. Näkyvien tyvimädän oireiden on kuitenkin todettu ilmenevän vasta, kun mukulassa on riittävästi bakteerisoluja (Rantanen ym., 2004). ELISA- tai PCR -menetelmillä voidaan määrittää piilevää tyvimätää aiheuttavan bakteerin esiintyminen ja määrä mukuloissa (Pérombelon, 2002). Näiden menetelmien käyttöä ja luotettavuutta rajoittaa kuitenkin se, että kustannussyistä määritys voidaan yleensä tehdä vain pienestä näyte- ja mukulamäärästä.

Erwinia-bakteerien infektioiden yhteydessä vapautuu haihtuvia yhdisteitä, jotka ovat näille bakteereille ominaisia (Waterer \& Pritchard, 1984; De Lacy Costello ym., 1999; Lyew ym., 2001, Kushalappa ym., 2002; Lui ym., 2005). Jos nämä yhdisteet voitaisiin mitata ja määrittää luotettavasti, piilevän tyvimädän infektio voitaisiin havaita ennen oireiden ilmenemistä. Aiemmissa tutkimuksissa analysointiin on käytetty kaasugromatografiaa/massaspektrometriaa sekä ns. elektronista nenää. Näillä menetelmillä on kuitenkin monia rajoituksia liittyen mm. mitattavien yhdisteiden konsentraatioihin ja yhdisteiden keräykseen (De Lacy Costello ym., 1999; Lyew ym., 2001). Uudenlaisella fotoakustiseen ilmiöön perustuvalla menetelmällä on mahdollista mitata halutun haihtuvan yhdisteen tai yhdisteseoksen erittäin pieniä pitoisuuksia avoimesta tilasta reaaliaikaisesti (Kauppinen ym., 2004.)

Tämän tutkimuksen tavoitteena oli selvittää, onko piilevän tyvimädän infektion tunnistaminen haihtuvien yhdisteiden perusteella mahdollista ennen näkyvien oireiden ilmenemistä ja mikä on piilevän tyvimätäinfektion paras indikaattori. Haihtuvien yhdisteiden määrittämistä varten pyrittiin kehittämään luotettava keräys- ja analysointimenetelmä, joka mahdollistaisi jatkotutkimukset.

\section{Aineisto ja menetelmät}

Perunalajikkeen Asterix mukuloita saastutettiin keinotekoisesti E. carotovora alalaji atroseptica bakteerilla. Eca-kantaa DSM 30186 kasvatettiin NB-liuoksessa 21-22 ${ }^{\circ} \mathrm{C}$ :ssa 18 tuntia. Kuhunkin mukulaan tehtiin korkkiporalla kaksi reikää (halkaisija $5 \mathrm{~mm}$, syvyys noin $10 \mathrm{~mm}$ ), joihin pipetoitiin 125 $\mu \mathrm{l}$ bakteerisuspensiota (1.8 E8 cfu/ml). Mukuloita inkuboitiin suljetussa kattilassa huoneenlämpötilassa $\left(21-23{ }^{\circ} \mathrm{C}\right)$. Kosteuden ylläpitämiseksi astian pohjalle lisättiin vettä. Kontrollimukuloihin pipetoitiin bakteerisuspension sijasta vettä ja niitä inkuboitiin omissa astioissaan samalla tavalla kuin saastutettuja mukuloita. Saastutetuista mukuloista ja kontrollimukuloista vapautuvia haihtuvien yhdisteitä analysoitiin eri ajankohtina SPME-GC-MS- (kiinteäfaasimikrouutto sekä kaasugromatografian ja massaspektrometria) (Shimadzu 5000QP) ja FTIR- (Fourier-muunnos infrapunaspektroskopia) (Gasmet FTIR) -menetelmillä. Koe toistettiin kahdeksan kertaa. Lisäksi tehtiin alustavia mittauksia varastolämpötilassa $\left(5^{\circ} \mathrm{C}\right)$. 


\section{Tulokset ja tulosten tarkastelu}

\section{SPME-GC-MS -analyysit}

SPME-GC-MS -menetelmä soveltui hyvin perunan mädäntyessä vapautuvien yhdisteiden keräämiseen, erotteluun ja tunnistamiseen. Mitattujen yhdisteiden suhteellisia osuuksia kaasufaasissa voitiin verrata toisiinsa, koska koejärjestely oli vakioitu. Sen sijaan yhdisteiden pitoisuuksia kaasufaasissa tai niiden absoluuttisia määriä ei voitu laskea tämän koesarjan perusteella. Huoneenlämpötilassa (21-23 ${ }^{\circ} \mathrm{C}$ ) saastuttamattomien kontrollimukuloiden ja Eca -bakteerilla saastutettujen mukuloiden välillä havaittiin ero keskimäärin 15-18 tunnin, parhaimmillaan jo 10 tunnin inkuboinnin jälkeen. Silmävaraisesti havaittavat tyvimädän oireet alkoivat ilmetä 48 tunnin kuluttua saastutuksesta. Sekä kontrolliettä saastutetuista mukuloista tunnistettiin hiilidioksidi ja rikkiyhdiste (Kuva 1). Saastutetuista perunoista havaittiin lisäksi alkoholeja (etanoli, 3-metyyli-1-butanoli, 2-metyyli-1-butanoli ja metyyli-1propanoli), etikkahappoa ja joitakin eri hapettumisasteisia 3-5 -hiilisiä yhdisteitä (Taulukko 1), joiden tunnistus oli epävarmaa alhaisen pitoisuuden ja samankaltaisten rakenteiden vuoksi. Saastutetuista perunoista vapautuneiden yhdisteiden kokonaismäärä lisääntyi moninkertaisesti inkubointiajan jatkuessa. Myös saastuttamattomissa kontrolliperunoissa tapahtui huomattavaa hengityksen lisääntymistä 48 tunnin kuluessa.

Perunoita säilytettiin varastossa maksimissaan 7 viikkoa. Varastolämpötilassa $\left(5^{\circ} \mathrm{C}\right)$ mädäntyvälle perunalle spesifisiä haihtuvia yhdisteitä havaittiin 48 tunnin kuluttua saastutuksesta. Koska tämä oli ensimmäinen mittauskerta, on mahdollista, että niitä on havaittavissa jo aiemmin. Silmävaraisesti havaittavat tyvimädän oireet alkoivat ilmetä viikon kuluttua saastutuksesta. Varastolämpötilassa sekä kontrolli- että saastutetuista perunoista vapautui samoja yhdisteitä kuin huoneenlämmössä säilytetyistä mukuloista (Taulukko 1).

\section{FTIR-analyysit}

FTIR-menetelmällä havaittiin huoneenlämpötilassa ero kontrolliperunoista ja Eca-bakteerilla saastutetuista mukuloista vapautuvien yhdisteiden välillä 12-18 tunnin inkuboinnin jälkeen. FTIR-mittauksissa selkeimmät muutokset tapahtuivat spektrin aallonpituusalueilla 3200-3500, 1900-2100 ja 900-1100 cm

${ }^{-1}$ (Kuva 2). Muutokset olivat pieniä, mikä osoittaa, että haihtuvat yhdisteet esiintyivät pieninä pitoisuuksina. Suurimmat muutokset havaittiin alueilla, joilla hiilidioksidi absorboi, ja näiden mittausten perusteella muutos hiilidioksidipitoisuudessa olikin selkein piilevän tyvimädän indikaattori. Toinen mahdollinen indikaattori oli karbonyylisulfidi (COS), mutta sitä havaittiin erittäin pieninä pitoisuuksina.

Varastolämpötilassa säilytettyjen kontrolli- ja saastutettujen mukuloiden välillä havaittiin selvä ero jo ensimmäisellä mittauskerralla kolmen vuorokauden kuluttua saastutuksesta. Muutokset spektrissä näkyivät samoilla aallonpituusalueilla kuin huoneenlämmössä, joten havaitut haihtuvat yhdisteet olivat samoja.

Näiden kokeiden perusteella FTIR-mittausmenetelmä soveltuisi kohtuullisen hyvin perunan tyvimädän havaitsemiseen. Jotta FTIR-mittausten perusteella voitaisiin analysoida luotettavasti eri aineiden pitoisuuksia, tulisi kyseisten aineiden olla melko tarkasti kartoitettu ja laite kalibroitu näille aineille. 
a)

b)
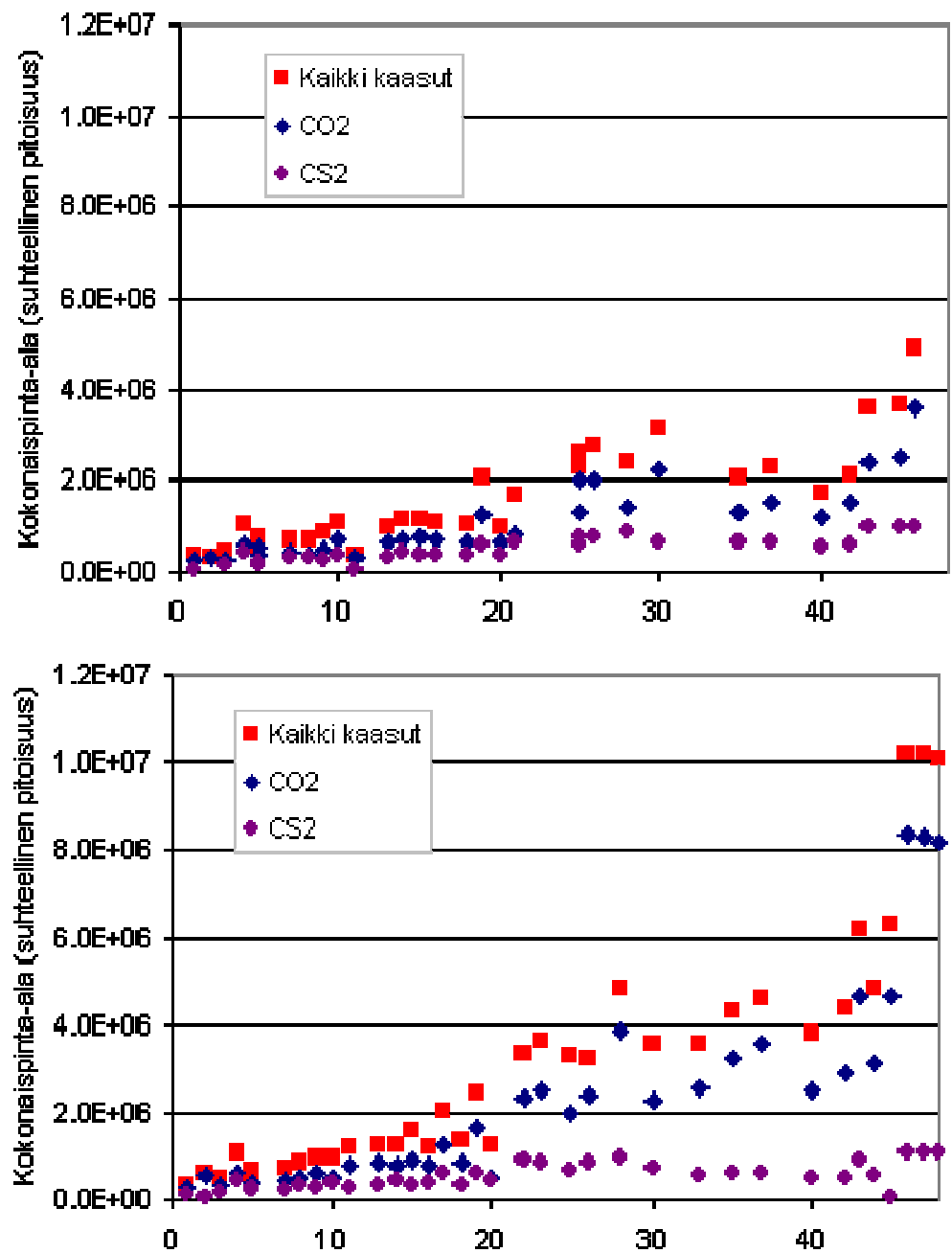

c)

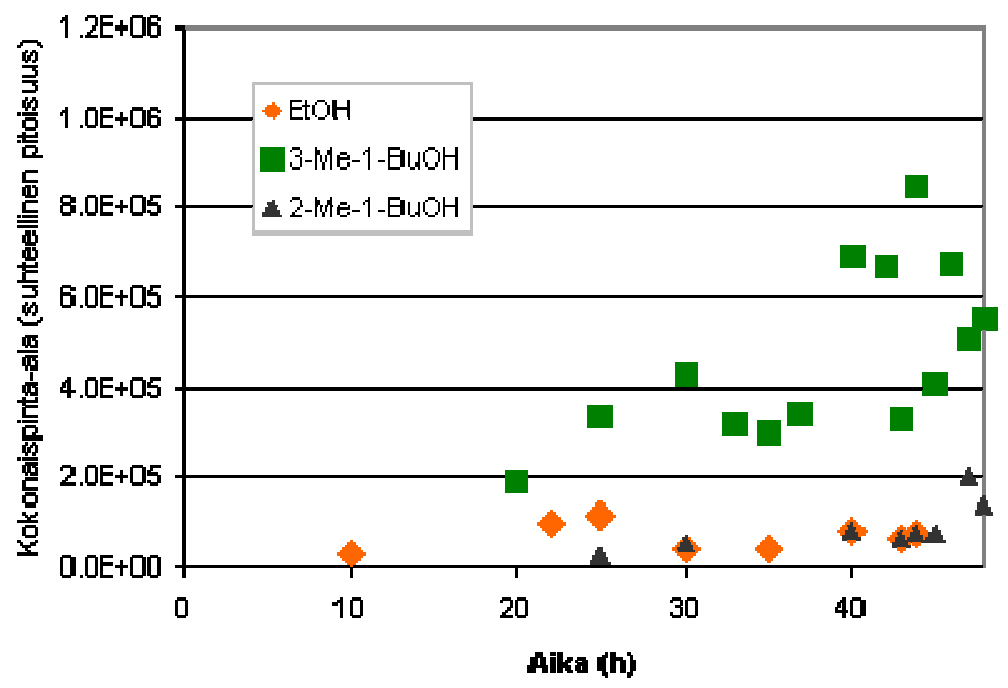

Kuva 1. Huoneenlämpötilassa $\left(21-23^{\circ} \mathrm{C}\right)$ säilytetyistä terveistä kontrolliperunoista (a) ja E. carotovora alalaji atroseptica -bakteerilla saastutetuista perunoista (b) ja (c) SMPE-GC-MS -menetelmällä havaittuja haihtuvia yhdisteitä 
Taulukko 1. Huoneenlämpötilassa $\left(21-23^{\circ} \mathrm{C}\right)$ ja varastolämpötilassa säilytetyistä $\left(5^{\circ} \mathrm{C}\right)$ terveistä kontrolliperunoista ja E. carotovora alalaji atroseptica -bakteerilla saastutetuista perunoista SMPE-GC-MS -menetelmällä kerätyt ja tunnistetut haihtuvat yhdisteet.

\begin{tabular}{|c|c|c|c|c|}
\hline \multirow[b]{2}{*}{ Haihtuva yhdiste } & \multicolumn{2}{|c|}{ Huoneenlämpötila $\left(21-22^{\circ} \mathrm{C}\right)$} & \multicolumn{2}{|c|}{ Varastolämpötila $\left(5^{\circ} \mathrm{C}\right)$} \\
\hline & $\begin{array}{c}\text { Eca- } \\
\text { saastutettu }\end{array}$ & Kontrolli & $\begin{array}{c}\text { Eca- } \\
\text { saastutettu }\end{array}$ & Kontrolli \\
\hline Hiilidioksidi & $\mathrm{x}$ & $\mathrm{x}$ & $\mathrm{x}$ & $\mathrm{x}$ \\
\hline Rikkiyhdiste & $\mathrm{x}$ & $\mathrm{x}$ & $\mathrm{x}$ & $\mathrm{x}$ \\
\hline Etanoli & $\mathrm{x}$ & & $\mathrm{x}$ & \\
\hline 3-metyyli-1-butanoli & $\mathrm{x}$ & & $\mathrm{x}$ & \\
\hline 2-metyyli-1-butanoli & $\mathrm{x}$ & & $\mathrm{x}$ & \\
\hline 3-hydroksi-2-butanoni & $\mathrm{x}$ & & $\mathrm{x}$ & \\
\hline 2-metyyli-1-propanoli & $\mathrm{x}$ & & $\mathrm{x}$ & \\
\hline 2-metyylipropanaali & $\mathrm{x}$ & & & \\
\hline 2-metyylipropanoni & $\mathrm{x}$ & & & \\
\hline 2-metyylipropaanihappo & $\mathrm{x}$ & & $\mathrm{x}$ & \\
\hline 1,3-butaanidioli & $\mathrm{x}$ & & $\mathrm{x}$ & \\
\hline 2,3-butaanidioni & $\mathrm{x}$ & & & \\
\hline Etikkahappo & $\mathrm{x}$ & & & \\
\hline Tunnistamaton, m/z 58 & $\mathrm{x}$ & & & \\
\hline Tunnistamaton, m/z 86/83 & $\mathrm{x}$ & $\mathrm{x}$ & $\mathrm{x}$ & $\mathrm{x}$ \\
\hline
\end{tabular}

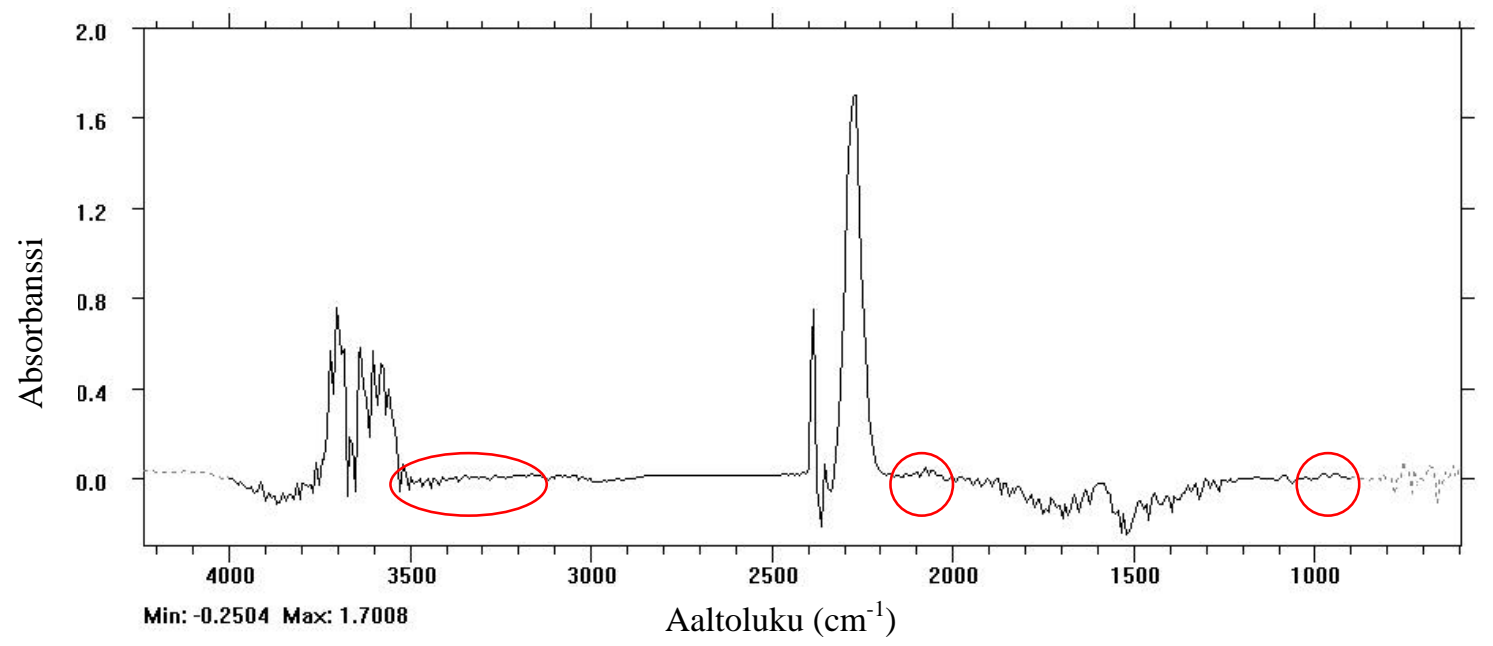

Kuva 2. Huoneenlämmössä $\left(21-23^{\circ} \mathrm{C}\right)$ säilytetyn E. carotovora alalaji atroseptica -bakteerilla saastutetun perunan FTIR-spektri 24 tuntia saastutuksen jälkeen. Alueet, joilla selkeimmät muutokset havaittiin, on rengastettu. Spektristä on vähennetty terveen perunan spektri. 


\section{Johtopäätökset}

Sekä SPME-GC-MS- että FTIR -menetelmillä voitiin osoittaa selvä ero terveestä ja Erwiniabakteerilla saastutetusta perunasta vapautuvien haihtuvien yhdisteiden välillä. SPME-GC-MS menetelmällä ero havaittiin 15-18 tunnin ja FTIR -menetelmällä 12-18 tunnin kuluttua saastutuksesta, kun perunat säilytettiin huoneenlämpötilassa $\left(21-23^{\circ} \mathrm{C}\right)$. Näkyvät mätänemisen oireet alkoivat ilmetä 48 tunnin kuluttua saastutuksesta. Samanlainen selvä ero saastutettujen ja saastuttamattomien perunoiden haihtuvissa yhdisteissä havaittiin, kun perunoita säilytettiin varastolämpötilassa $\left(5^{\circ} \mathrm{C}\right)$.

SPME-GC-MS -menetelmällä saastutetuista mukuloista pystyttiin keräämään ja tunnistamaan useita yhdisteitä, joita terveistä kontrolliperunoista ei havaittu. Nämä yhdisteet olivat haaroittuneita alkoholeja, ketoneita ja aldehydejä, jotka voivat muodostua pektolyyttisten entsyymien aktiivisuuden seurauksena. FTIR- menetelmällä paras piilevän tyvimädän indikaattori oli hiilidioksidi.

Sekä SPME-GC-MS- että FTIR -menetelmät soveltuivat perunoista vapautuvien haihtuvien yhdisteiden määritykseen laboratorio-oloissa, sillä molemmilla menetelmillä voitiin osoittaa selvä ero terveen ja Erwinia-bakteerilla saastutetun perunan välillä. Menetelmien optimoinnilla ja validoinnilla voidaan saada tarkempia tuloksia mm. yhdisteiden absoluuttisista pitoisuuksista. Kumpikaan menetelmä ei sellaisenaan sovellu piilevän tyvimädän tunnistamiseen tuotanto-oloissa, mutta näillä menetelmillä voidaan kerätä aineistoa, joka mahdollistaa kenttäkelpoisen sovelluksen kehittämiseen.

Tähänastisissa kokeissa on määritetty vain yhden tyvi- ja märkämädän aiheuttajan infektiossa vapautuvia haihtuvia yhdisteitä yhdellä perunalajikkeella. Jatkotutkimuksissa tulisi selvittää myös muiden tyvi- ja märkämätää aiheuttavien Erwinia-bakteerien, perunalajikkeen ja muiden perunaa mädättävien organismien vaikutuksia haihtuvien yhdisteiden muodostumiseen ja vapautumiseen eri ympäristöoloissa.

\section{Kirjallisuus}

De Lacy Costello B.P.J., Evans, P., Ewen, R.J., Gunson, H.E., Ratcliffe, N.M. \& Spencer-Phillips, P.T.N. 1999. Identification of volatiles generated by potato tubers (Solanum tuberosum CV: Maris Piper) infected by Erwinia carotovora, Bacillus polymyxa and Arthrobacter sp. Plant Pathology 48: 345-351.

Kauppinen, J., Wilcken, K, Kauppinen, I \& Koskinen, V. 2004. High sensitivity in gas analysis with photoacoustic detection. Microchemical Journal 76: 151-159.

Kushalappa, A.C., Lui, L.H., Chen, C.R. \& Lee, B. 2002. Volatile fingerprinting (SPME-GC-FID) to detect and discriminate diseases to potato tubers. Plant Disease 86: 2,131-137.

Lui, L.H., Vikram, A., Abu-Nada, Y., Kushalappa, A.C., Raghavan, G.S.V. \& Al-Mughrabi, K. 2005. Volatile metabolic profiling and discrimination of potato tubers inoculated with dry and soft rot pathogens. Amererican Journal of Potato Research 82: 1-8.

Lyew, D., Gariepy, Y., Raghavan, G.S.V. \& Kushalappa, A.C. 2001. Changes in volatile production during an infection of potatoes by Erwinia carotovora. Food Research International 34: 807-813.

Pérombelon, M.C.M. 2002. Potato diseases caused by soft rot Erwinias: an overview of pathogenesis. Plant Pathology 51: 1-12.

Pérombelon, M.C.M. \& Kelman, A. 1987. Blackleg and other potato diseases caused by soft rot Erwinias: proposal for revision of terminology. Plant Disease 71: 282-285.

Rantanen, T., Moisio, T. \& Suokas, M. 2004. Piilevän tyvimätätartunnan toteamiseen käytettävät PCRmenetelmät. Teoksessa: Hannukkala, A. \& Segersted, M. (toim.) Perunantyvi- ja märkämädän epidemiologia, diagnostiikka ja hallintakeinot. Maa- ja elintarviketalous 41. Maa- ja elintarviketalouden tutkimuskeskus.

Waterer, D.R. \& Pritchard, M.K. 1984. Monitoring of volatiles: A technique for detection of soft rot (Erwinia SPME-GC-MS -menetelmällä carotovora) in potato tubers. Canadian Journal of Plant Pathology. 6: 165171. 